\title{
研究論文
}

\section{Influence and Interference by Thymol added as a Biocide on the Analysis of Precipitation Samples}

\author{
Yangang Wang* ${ }^{*}$ Masahide Aikawa ${ }^{*} \cdot$ Takatoshi Hiraki ${ }^{* *}$ \\ Mitsuru Shoga $* * *$ Motonori Tamaki****
}

\section{殺菌剤として添加されたチモールが降水武料の分析に与える影響・妨害}

王彦剛**藍川昌 秀**.平木隆年**.正賀 充***.玉置元 則 ${ }^{* *}$

\section{要旨}

現在，酸性雨現象は，雨，雪や霧を対象とした湿性沈着と非降水時のガスや粒子を対象とした乾性沈着の両 者を含めて評価されているが，測定の基本はいかに正確に降水を捕集し化学成分を分析するかという点から出 発する. 降水中の化学成分は微生物活動, 光や熱の影響, 大気中気体成分の吸収ならびに共存する粒子状物質 との相互作用によって変質する，そのため，試料採取においては，冷却，ろ過，遮光ならびに密閉などの対策 をとる必要がある。このうち, 冷却の目的で冷蔵庫内蔵型のサンプラーの使用が推奨されているが, どうして も高価な装置とならざるをえない。一方, 酸性雨現象は大陸内程度の中一長距離輸送による酸性物質の大気中 ならびに雲中での硫酸や硝酸への化学的変化過程に基づくとされるため, 広域的な監視網の形成が必要である. この目的で，2000年から日本，中国，韓国を中心とした東アジア酸性雨モニタリングネットワーク（EANET) が立ち上げられ，2001年からは測定が開始されている。この中で，夏季の試料ならびに熱带地域周辺の国々の 試料においては，試料採取後の化学成分の変質防止が大きな課題となっている．チモール（2-イソプロピル -5-メチルフェノール）は降水試料を採取・保存する際に冷蔵庫が使用できない場合の殺菌剂としてその使用 が推奨されている，確かにチモールは有効な殺菌剤であることが証明されてきたが，他方，チモールは降水試 料を分析する際に分析に影響・妨害を与える可能性がある. 本研究では, 事前に容器中に一定量のチモールを 添加する採取法を想定し，そのことが，降水試料の $\mathrm{pH}$ 測定や吸光光度法での化学成分測定におよぼす影響を 調べた。

$10^{-4} \mathrm{M}(\mathrm{mol} / \mathrm{l})$ の $\mathrm{KCl}$ 溶液の $\mathrm{pH}$ はチモールの添加量が100 mg/100 mlを超えると低下した．その一方， 実際の降水試料のいくつかではチモールの添加量が $10 \mathrm{mg} / 100 \mathrm{~m} \ell$ 以下であると $\mathrm{pH}$ は上昇し, $100 \mathrm{mg} / 100 \mathrm{~m} \ell$ 以 上であると $\mathrm{pH}$ は低下した. $\mathrm{NH}_{4}{ }^{+}$（アンモニウムイオン）を分析する際に吸光光度法であるインドフェノー ル青法を用いる場合はチモールを添加することにより吸光度が低下したが，これはインドフェノール青法を用 いる際に添加するフェノールと殺菌䨩として添加したチモールの競争反応によると考えられる．インドフェノ 一ル青法において吸光度がどの程度低下寸るかは添加されたチモールの濃度によるが，試料採取する際に添加 するチモール量は試料採取容器をセットする前に一定量を加えるため, 試料採取後にチモール濃度が試料中で いくらになるかは調整できない，このことから $\mathrm{NH}_{4}{ }^{+}$を分析する際にインドフェノール青法を用いる場合はチ モールを添加することは分析上適さない.

また，同様の吸光光度法である，塩化物イオン分析用のチオシアン酸第二水銀法，硝酸イオン分析用のサリ チル酸ナトリウム法および硫酸イオン分析用の硫酸バリウム比濁法についても，吸光度に与えるチモールの影 響を調べたが，いずれも影響は認められなかった。

キーワード : 酸性雨, インドフェノール青法, $\mathrm{pH}$, 降水, チモール

* Guangdong Province Environmental Protection Monitoring Center

2005年 8 月 24 日受付

** Hyogo Prefectural Institute of Public Health and Environmental Sciences 2005年10月29日受理

$* * *$ Air Pollution Control Division, Office of Hyogo Prefecture

$* * * *$ Hyogo Environmental Advancement Association 


\section{INTRODUCTION}

Acid rain has attracted attention as a regional-scale environmental issue in Europe and North America since the beginning of the 1970 's. Recently, the acid rain issue has extended to East Asia because of a significant increase in anthropogenic emissions of sulfur dioxide, nitrogen oxides, and other substances to the atmosphere due to high economic growth in the region. The region is increasingly facing threats of acid deposition, and it is becoming essential to struggle against these threats through regional cooperation and the efforts of individual countries. The Acid Deposition Monitoring Network in East Asia (EANET) was organized in 2000 to create a common understanding among countries and organizations of the status of acid deposition in the region. Regular phase monitoring started in 2001 based on Technical Documents in East Asia').

Precipitation samples should be collected without degeneration. Thymol is a biocide effectively used to prevent samples from degenerating ${ }^{2,3)}$. Technical Documents recommends using thymol as a biocide unless refrigeration can be used for the preservation of precipitation samples. However, the addition of thymol to precipitation samples interferes with the determination of chemical species in some analytical methods.

This paper evaluates the influence and the interference by thymol on $\mathrm{pH}$ analysis and colorimetric methods, especially indophenol blue method for $\mathrm{NH}_{4}{ }^{+}$analysis of analyzing precipitation samples in the actual use of thymol as a biocide. The ion chromatograph has been used worldwide for the determination of chemical species. However colorimetric methods or titration methods have been used for the determination of chemical species in some countries in the above EANET.

\section{EXPERIMENTAL}

\subsection{Solubility of Thymol for Deionized Water and Dilute $\mathrm{KCl}$ Solution}

The solubility of thymol for deionized water and dilute $\mathrm{KCl}$ solution was examined. Ten, 20, 40, 100,200 , and $500 \mathrm{mg}$ thymol were added to $100 \mathrm{~m} \ell$ deionized water and dilute $\mathrm{KCl}$ solution $\left(10^{-4} \mathrm{M}\right)$. The reason that dilute $\mathrm{KCl}$ solution was used is described in 2.2. The solutions were left at room temperature (approximately 20 $\mathrm{C}$ ) for 1 day. After 1 day, the thymol that did not dissolve was filtrated and weighted. The solubility was calculated by the difference of thymol between the added and remaining amounts.

\subsection{Influence on $\mathrm{pH}$ Measurement for Dilute $\mathrm{KCl}$ Solution}

Deionized water is not suitable for the examination of $\mathrm{pH}$ measurement because it is easily influenced by carbon dioxide in the atmosphere. A dilute $\left(10^{-4} \mathrm{M}\right)$ of potassium chloride $(\mathrm{KCl})$ solution was, therefore, used as a neutral solution to examine the influence of thymol on $\mathrm{pH}$ measurement. The $\mathrm{pH}$ value was measured with $0,10,40,200$, and $1000 \mathrm{mg}$ thymol added to $100 \mathrm{~m} l$ dilute $\mathrm{KCl}$ solution. The $\mathrm{pH}$ value of the dilute $\mathrm{KCl}$ solution was measured 1 hour after the thymol was added.

\subsection{Influence on $\mathrm{pH}$ Measurement for Pre- cipitation Samples}

\subsubsection{Collection of precipitation samples}

Four identical filtering-type bulk samplers ${ }^{4)}$ were used to collect precipitation samples. The collection was conducted on the roof of the institute (25 $\mathrm{m}$ above ground level) in summer (average air temperature: about $24^{\circ} \mathrm{C}$; maximum air temperature: about $40^{\circ} \mathrm{C}$ ). Fifty $\mathrm{mg}, 200 \mathrm{mg}$, $1000 \mathrm{mg}$, or $5000 \mathrm{mg}$ thymol was added to the four samplers before the collection was started. The samples were collected weekly and stored in polyethylene bottles at room temperature (about $15^{\circ} \mathrm{C}$ ). The weekly precipitation amount in Japanese fiscal year (April-March) 2000 is 
as follows: mean $436.5 \mathrm{~m} \ell(19.2 \mathrm{~mm})$, maximum $2750 \mathrm{~m} \ell(121.2 \mathrm{~mm})$, minimum $0 \mathrm{~m} \ell(0 \mathrm{~mm})$ and standard deviation $614.9 \mathrm{ml}(27.1 \mathrm{~mm})$.

\subsection{2 $\mathrm{pH}$ measurement of precipitation samples}

After collection, the samples were analyzed four times: as soon as possible after collection, 1 month later, 2 months later, and 3 months later.

\subsection{Influence on Colorimetric Methods}

The influence on colorimetric methods for $\mathrm{NH}_{4}{ }^{+}$ (indophenol blue method ${ }^{5)}, \mathrm{Cl}^{-}\left(\mathrm{Hg}(\mathrm{SCN})_{2}\right.$ method $)^{6)}, \mathrm{NO}_{3}{ }^{-}\left(\mathrm{HOC}_{6} \mathrm{H}_{4} \mathrm{COONa} \text { method }\right)^{7)}$, and $\mathrm{SO}_{4}{ }^{2-}$ (barium sulfate turbidimetry) ${ }^{8)}$ was examined. Seven series of $100 \mathrm{~m} \ell \mathrm{NH}_{4}{ }^{+}$standard solution (about $0.1 \mathrm{nM}$ ) with different amounts of thymol $(0,1,2,3,4,5$, and $20 \mathrm{mg})$ were analyzed by the indophenol blue method. Five series of $100 \mathrm{ml} \mathrm{Cl}^{-}$(about $0.7 \mathrm{nM}$ ), $\mathrm{NO}_{3}{ }^{-}$(about $0.2 \mathrm{nM}$ ), and $\mathrm{SO}_{4}{ }^{2-}$ (about $1.0 \mathrm{nM}$ ) standard solution with different amounts of thymol $(0,10$, 40, 200, and $1000 \mathrm{mg}$ ) were analyzed by the $\mathrm{Hg}$ $(\mathrm{SCN})_{2}$ method, the $\mathrm{HOC}_{6} \mathrm{H}_{4} \mathrm{COONa}$ method, and barium sulfate turbidimetry, respectively.

\section{RESULTS AND DISCUSSION}

\subsection{Solubility of Thymol for Deionized Water and Dilute $\mathrm{KCl}$ Solution}

The dissolved amounts of thymol were 9.0, 18.8, 32.4, 41.9, 66.3, and $92.2 \mathrm{mg}$ for 10, 20, 40, 100, 200 , and $500 \mathrm{mg}$ of thymol added to $100 \mathrm{ml}$ deionized water, respectively. Similarly, the dissolved amounts for the dilute $\mathrm{KCl}$ solution were $8.9,15.3,27.0,44.8,63.9$, and $99.4 \mathrm{mg}$. In Technical Documents, $400 \mathrm{mg}$ thymol per 1,000 $\mathrm{m} \ell$ solution is recommended ${ }^{1)}$. The result shows, however, a possibility of excessive dissolution over the recommendation of Technical Documents. A disadvantage of excessive dissolution over the recommendation is described in the following section.

\subsection{Influence on $\mathrm{pH}$ Measurement for Dilute $\mathrm{KCl}$ Solution}

The dependence of the $\mathrm{pH}$ value of the dilute $\mathrm{KCl}$ solution on the amount of thymol added is shown in Fig. 1. The $\mathrm{pH}$ value decreased as the amount of added thymol was increased. This result was probably due to the dissociation of thymol, as shown in Fig. 2. In Technical Documents, $400 \mathrm{mg}$ thymol per $1000 \mathrm{~m} \ell$ solution is recommended as mentioned above ${ }^{1)}$. Fig. 1 shows that the $\mathrm{pH}$ value was affected only a little by the amount of thymol added, up to 400 $\mathrm{mg} / 1000 \mathrm{ml}$ dilute $\mathrm{KCl}$ solution. However, with the use of thymol for precipitation samples, the limitation that will be discussed in 3.3 .2 was accompanied.

\subsection{Influence on $\mathrm{pH}$ Measurement for Pre- cipitation Samples}

\subsubsection{Collection of precipitation samples}

Twelve series of samples (No. $1 \sim$ No. 12) were collected. The precipitation levels are given in Table. No significant $(\mathrm{p}>0.05)$ difference on precipitation was caused by the difference in the amount of thymol added before starting collection, showing that the four samples within each series could be evaluated equally.

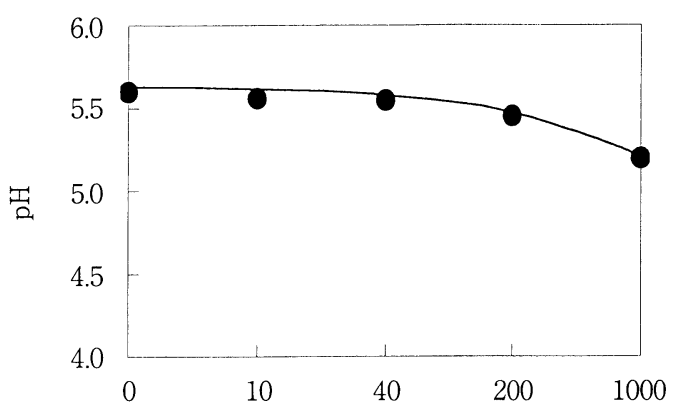

Amount of thymol added (mg/100ml solution)

Fig. 1 Dependence of the $\mathrm{pH}$ value of the dilute $\mathrm{KCl}$ solution on the amount of thymol added

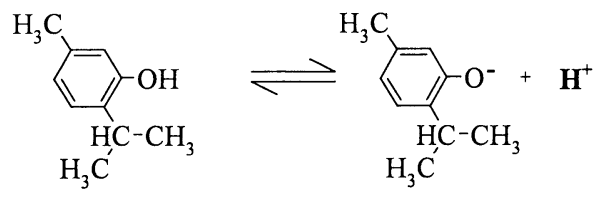

Fig. 2 Dissociation of thymol 
Table Precipitation levels from No.1 to No.12

unit : $\mathrm{m} \ell$

\begin{tabular}{ccccccccccccc}
\hline $\begin{array}{c}\text { Amout of thymol } \\
\text { added }\end{array}$ & No.1 & No.2 & No.3 & No.4 & No.5 & No.6 & No.7 & No.8 & No.9 & No.10 & No.11 & No.12 \\
\hline $50 \mathrm{mg}$ & 556 & 1066 & 490 & 279 & 541 & 197 & 570 & 512 & 295 & 267 & 619 & 204 \\
\hline $200 \mathrm{mg}$ & 556 & 965 & 432 & 278 & 526 & 187 & 562 & 510 & 301 & 281 & 611 & 216 \\
\hline $1000 \mathrm{mg}$ & 583 & 1071 & 480 & 276 & 523 & 190 & 564 & 511 & 292 & 269 & 596 & 212 \\
\hline $5000 \mathrm{mg}$ & 578 & 1068 & 506 & 278 & 550 & 192 & 589 & 528 & 325 & 283 & 660 & 220 \\
\hline
\end{tabular}

- 1 month later -2 months later $\times 3$ months later

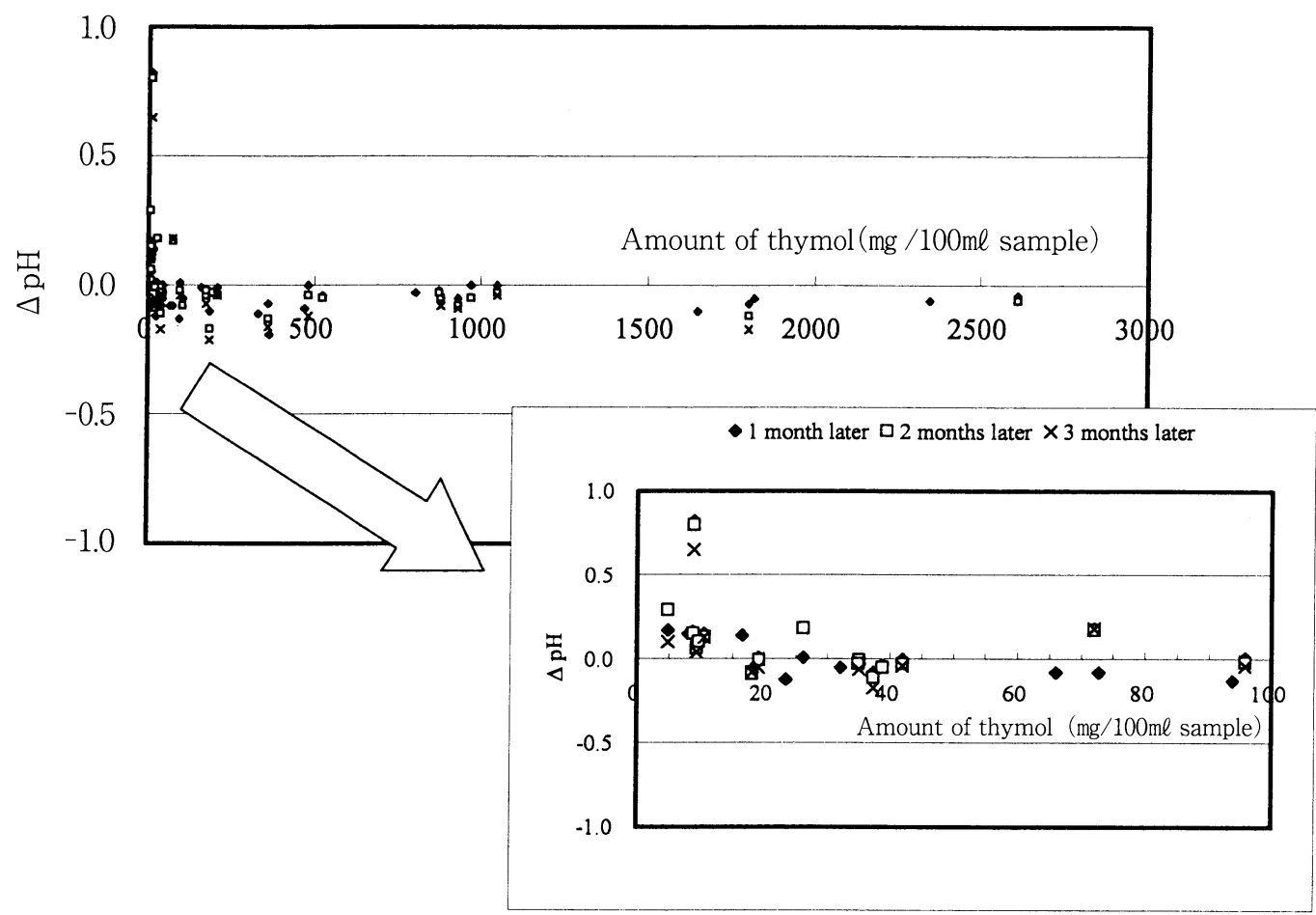

Fig. 3 Plots on the amount of thymol vs.

$\Delta \mathrm{pH} . \Delta \mathrm{pH}$ is defined as $\mathrm{pH}_{i j k}-\mathrm{pH}_{i j}(O$ month $)$ for $i=$ amount of thymol added before starting collection $(50,200,1000$, and $5000 \mathrm{mg}$ ), $j=$ the series number of the precipitation samples (No. $1 \sim$ No. 12 ), and $k=$ the number of months before measurement ( 1 month, 2 months, and 3 months)

\subsection{2 $\mathrm{pH}$ measurement for precipitation sam- ples}

The plots of the amount of thymol vs. $\Delta \mathrm{pH}$ are shown in Fig. 3, where $\Delta \mathrm{pH}$ is defined as $\mathrm{pH}_{i j k}-\mathrm{pH}_{i j}$ (O month) for $i=$ amount of thymol added before starting collection $(50,200,1000$, and $5000 \mathrm{mg}$ ), $j=$ the series number of the precipitation samples (No. 1 No. 12), and $k=$ the number of months before measurement ( 1 month, 2 months, and 3 months). The horizontal axis is shown by the unit of $\mathrm{mg} / 100 \mathrm{~m} \ell$ sample, which was calculated based on the amount of thymol (50, 200, 1000, and $5000 \mathrm{mg}$ ) / the precipitation collected, as shown in Table. The $\mathrm{pH}$ values in some samples increased when the amount of thymol contained in the samples was less than $10 \mathrm{mg} / 100 \mathrm{~m} \ell$ sample. This result was probably due to an inadequate amount of thymol. In contrast, the $\mathrm{pH}$ values decreased slightly when the amount of thymol contained in the 
samples was more than $100 \mathrm{mg} / 100 \mathrm{~m} \ell$ sample. Technical Documents requires that thymol should be added before starting collection to prevent samples from degenerating during the collection $^{1)}$. However, it is impossible to predict the amount of precipitation that will be collected. As a result, the amount of thymol that will be contained in the precipitation samples will be different for each sample. A limitation is presented here. The amount of thymol contained in the samples will be small when the amount of precipitation is large. A small amount of thymol

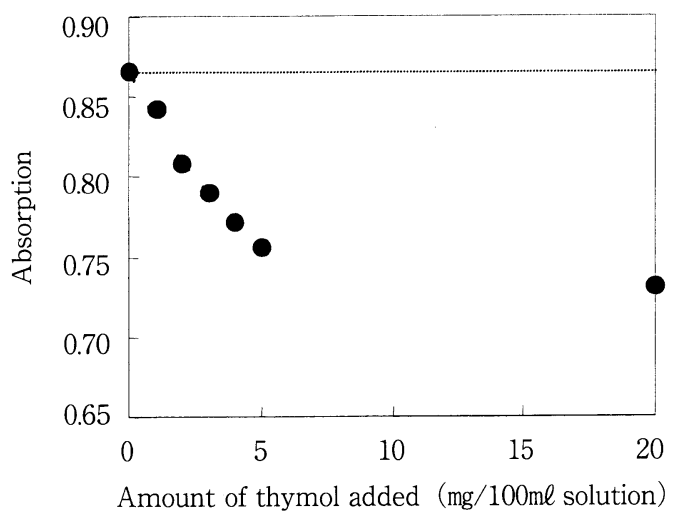

Fig. 4 Change in absorption in the indophenol blue method by the addition of thymol will result in an increase in the $\mathrm{pH}$ value, as shown above. On the other hand, an excess amount of added thymol will lead to a decrease in the $\mathrm{pH}$ value.

\subsection{Influence on Colorimetric Methods}

\subsubsection{Influence on indophenol blue method}

Fig. 4 shows the change in absorption in the indophenol blue method when different amounts of thymol $(0,1,2,3,4,5$, and $20 \mathrm{mg})$ were added to the seven series of $\mathrm{NH}_{4}{ }^{+}$standard solution. The absorption decreased with an increase of the amount of thymol added.

A chemical reaction occurred in the indophenol blue method, as shown in Fig. 5 (a). The chemical structures of phenol and thymol are also shown in Fig. 5(b). The blue color in the indophenol blue method is due to the product caused by the reaction shown in Fig. 5 (a). The chemical structure of thymol, which is similar to that of phenol, makes it possible to substitute thymol for phenol through a competitive reaction, which is responsible for the decrease in the formation of the product that is due to the blue color. As a result, the absorption in the indophenol blue method decreases with

(a)

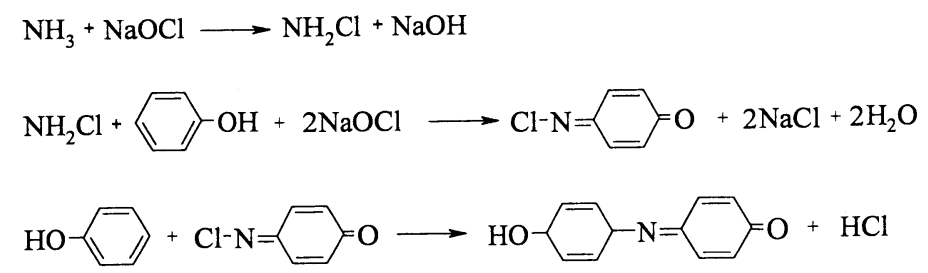

(b)

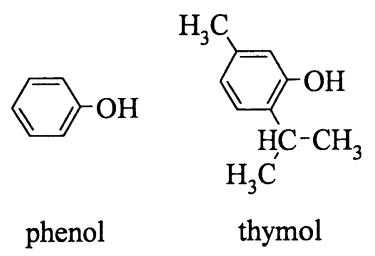

Fig. 5 (a) Chemical reaction occurred in the indophenol blue method, and (b) chemical structure of phenol and thymol 
the addition of thymol.

The decrease in the absorption is dependent on the amount of thymol added to the sample solution. However, it is impossible to control the amount of thymol to be contained in sample solution, as mentioned above. Consequently, the indophenol blue method cannot be recommended for samples to which thymol is added before starting collection.

\subsubsection{Influence on other colorimetric methods}

The influences on the $\mathrm{Hg}(\mathrm{SCN})_{2}$ method, the $\mathrm{HOC}_{6} \mathrm{H}_{4} \mathrm{COONa}$ method, and barium sulfate turbidimetry are shown in Fig. 6. The addition of thymol apparently had no influence on these colorimetric methods.

\section{CONCLUSIONS}

The influence and the interference of thymol, which is recommended for the preservation of precipitation samples unless refrigeration can be used, were examined with respect to the analysis of samples. The $\mathrm{pH}$ value of dilute $\mathrm{KCl}$ solution decreased when the amount of thymol added was more than $100 \mathrm{mg} / 100 \mathrm{~m} \ell \mathrm{KCl}$ solution. In contrast, the $\mathrm{pH}$ value increased when the amount of thymol added was less than $10 \mathrm{mg}$ $/ 100 \mathrm{~m} \ell$ precipitation sample. An influence on the analysis of $\mathrm{pH}$ by the addition of thymol was inevitable because it was impossible to predict the amount of precipitation collected. The absorbance in the indophenol blue method decreased with the addition of thymol because its chemical structure is similar to that of phenol. Using the indophenol blue method to analyze precipitation samples to which thymol is added before starting collection is not recommended. In contrast, the addition of thymol did not influence

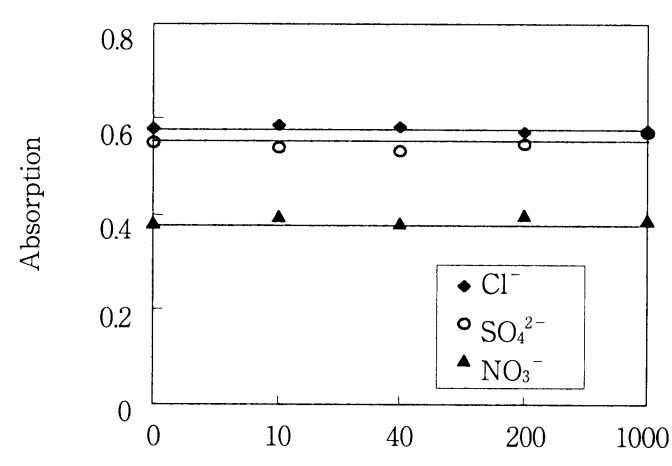

Amount of thymol added (mg/100ml solution)

Fig. 6 Influences on the $\mathrm{Hg}(\mathrm{SCN})_{2}$ method, the $\mathrm{HOC}_{6} \mathrm{H}_{4} \mathrm{COONa}$ method, and barium sulfate turbidimetry

other colorimetric methods such as the $\mathrm{Hg}(\mathrm{SCN})_{2}$ method, the $\mathrm{HOC}_{6} \mathrm{H}_{4} \mathrm{COONa}$ method, and barium sulfate turbidimetry.

\section{REFERENCES}

1 ) Technical Documents for Wet Deposition Monitoring in East Asia, The Second Interim Scientific Advisory Group Meeting of Acid Deposition Monitoring Network in East Asia (2000)

2 ) Gillett, R.W. and G.P. Ayers : The use of thymol as a biocide in rainwater samples, Atmospheric Environment, 25A: 2677-2681 (1991)

3 ) Ayers, G.P., N. Fukuzaki, R.W. Gillett, J.C. Selleck and H. Hara: Thymol as a biocide in Japanese rainwater, Journal of Atmospheric Chemistry, 30, 301-310 (1998)

4 ) Tamaki, M., T. Hiraki and M. Aikawa : Progress in acid deposition monitoring technology in Japan, Global Environmental Research, 4 (1), 25-38 (2000)

5 ) Rommers, P.J. and J. Visser : Spectrophotometric determination of micro amounts of nitrogen as indophenol, Analyst, 94, 653-658 (1969)

6 ) Iwasaki, J., S. Utsumi, K. Hagino and T. Ozawa : A new spectrophotometric method for the determination of small amount of chloride using the mercuric thiocyanate method, Bulletin of the Chemical Society of Japan, 29, 860-864 (1956)

7 ) Pharmaceutical Society of Japan : Standard methods of analysis for hygienic chemists. Tokyo, JAPAN: KANEHARA\&CO., LTD (1990)

8 ) American Society for Testing and Materials, Standard test methods for sulfate ion in water, D516-82 (1982) 


\title{
Influence and Interference by Thymol added as a Biocide on the Analysis of Precipitation Samples
}

\author{
Yangang Wang ${ }^{*}$, Masahide Aikawa ${ }^{* *}$, Takatoshi Hiraki ${ }^{* *}$ \\ Mitsuru Shoga ${ }^{* * *}$, Motonori Tamaki ${ }^{* * *}$
}

\begin{abstract}
Thymol (2-isopropyl-5-methyl phenol) is recommended for the preservation of precipitation samples to suppress the microbial activity and conversion of organic acids unless refrigeration can be used. However, the addition of thymol to precipitation samples influences and interferes with the analysis of samples. The $\mathrm{pH}$ value of dilute $\left(10^{-4} \mathrm{M}\right) \mathrm{KCl}$ solution decreased when the amount of thymol added was more than $100 \mathrm{mg} / 100 \mathrm{~m} \ell$ dilute $\mathrm{KCl}$ solution. In contrast, the $\mathrm{pH}$ value increased when the amount of thymol added was less than $10 \mathrm{mg}$ $/ 100 \mathrm{~m} \ell$ precipitation sample. The absorbance in the colorimetric method (indophenol blue method for $\mathrm{NH}_{4}{ }^{+}$ analysis) was decreased by the addition of thymol. This result was probably caused by the competitive reaction of thymol and phenol through their similar chemical structures. The decrease in the absorbance was dependent on the amount of thymol added. Therefore, the indophenol blue method cannot be recommended for samples to which thymol is added before starting collection because it is impossible to add an appropriate amount of thymol.
\end{abstract}

Key Words : Acid rain, Indophenol blue method, pH, Precipitation, Thymol

\section{募集案內}

\section{平成18・19年度採用分 特別研究員 - RPD 募集}

(独) 日本学術振興会では, 特別研究員事業の一環として, 優れた若手研究者が出産・育児による 研究中断後, 円滑に研究現場に復帰する環境を整備するため, 研究奨励金を一定期間支給し, 研究 活動再開を支援する特別研究員 - RPD を平成18年度より創設.

今回，平成18年度と平成19年度採用分の募集を同時に行なう.

記

申請資格: 大学院博士課程修了者等で, 平成18年 4 月 1 日から遡り過去 5 年以内に, 出産または子 の養育のため, 概ね 3 ケ月以上やむを得ず研究活 動を中断した者（年齢・性別不問）.

\section{採用期間 :}

[平成18年度採用分］

平成19年 1 月 1 日 平成 20 年 12 月 31 日

[平成19年度採用分］

平成 19 年 4 月 1 日 平成 21 年 3 月 31 日

平成19年 7 月 1 日～平成 21 年 6 月 30 日

平成 19 年 10 月 1 日 平成 21 年 9 月 30 日
平成 20 年 1 月 1 日～平成 21 年12月31日

申請書提出方法 :

研究に従事する予定の機関を通じて提出する.

受付期間 :

平成18年 6 月 5 日 6 月 9 日（必着）

問い合わせ先 :

(独) 日本学術振興会

于102-8472 東京都千代田区一番町 8 番地

TEL 03-3263-1736, 5070

URL http://www.jsps.go.jp/ 